\section{Effect of physiological priming on stored coffee seeds}

\author{
Amanda Carvalho Penido ${ }^{1 *}$ (D) Édila Maria de Rezende ${ }^{2}$ (D) , Diego de Sousa \\ Pereira $^{1}$ (D), Venícius Urbano Vilela Reis ${ }^{1}$ (D), Debora Kelli Rocha ${ }^{1}$ (D), João
} Almir Oliveira ${ }^{1}$

ABSTRACT: The physiological priming has been used to standardize and increase the speed of development of seed lots. The use of this technique is essential in coffee cultivation, as the crop has low longevity associated with slow and uneven germination. The objective was to evaluate the effect of physiological priming on the physiological quality of coffee seeds stored with different water contents. Seeds of two cultivars of Coffea arabica were used: cv. Catuaí Vermelho IAC144 and Topázio MG1190. A portion of the seeds were dried in the shade until reaching $12 \%$ moisture, and the other did not undergo drying. The seeds were stored in a cold chamber at $10{ }^{\circ} \mathrm{C}$ for nine months. Every three months, the physiological priming technique was performed with subsequent evaluation of the physiological quality by germination tests, root protrusion, normal seedlings at fifteen days, strong normal seedlings, seedlings with expanded cotyledonary leaves and seedling dry weight. Seeds that did not undergo drying subjected to the physiological priming technique maintained physiological quality after nine months of storage. Physiological priming was detrimental to dry seeds stored for nine months.

Index terms: Coffea arabica, hidropriming, water content, storage.

RESUMO: O condicionamento fisiológico é utilizado para uniformizar e aumentar a velocidade de desenvolvimento de lotes de sementes. Essa técnica é essencial na cafeicultura, pois a cultura apresenta baixa longevidade associada à germinação lenta e desuniforme. O objetivo foi avaliar a influência do condicionamento fisiológico na qualidade fisiológica de sementes de café armazenadas com diferentes teores de água. Sementes de duas cultivares Coffea arabica: cv. Catuaí Vermelho IAC144 e Topázio MG1190. Uma porção das sementes foram secas a sombra até $12 \%$ e a outra parte não passou por processo de secagem. As sementes foram armazenadas em câmara fria a $10{ }^{\circ} \mathrm{C}$ durante nove meses. A cada três meses de armazenamento, foi realizada a técnica de condicionamento fisiológico, com posterior avaliação da qualidade fisiológica pelos testes de germinação, protrusão radicular, plântulas normais aos quinze dias, plântulas normais fortes, plântulas com folhas cotiledonares expandidas e massa seca de plântulas. As sementes que não passaram pelo processo de secagem e submetidas ao condicionamento fisiológico, mantêm a qualidade fisiológica após nove meses de armazenamento. $O$ condicionamento fisiológico é prejudicial às sementes secas armazenadas durante nove meses.

Termos para indexação: Coffea arabica, hidrocondicionamento, teor de água, armazenamento.
Journal of Seed Science, v.43, e202143027, 2021

http://dx.doi.org/10.1590/ 2317-1545v43246448
$*$ Corresponding author
E-mail: apenidoufla@gmail.com

Received: 12/10/2020.

Accepted: 8/24/2021.

\footnotetext{
${ }^{1}$ Universidade Federal de Lavras (UFLA), Caixa Postal 3037, 37200900 - Lavras, MG, Brasil.

${ }^{2}$ Universidade Federal de Uberlândia (UFU), 38500-000 Monte Carmelo, MG, Brasil.
} 


\section{INTRODUCTION}

Coffee is considered one of the most important agricultural products, with great importance in the national and international markets. Brazil is the largest coffee producer in the world, and this industry has a strong impact on the country's economy (CONAB, 2020).

Coffee plants are propagated using seedlings obtained from seeds; therefore, the use of quality seeds is a determinant production factor. According to Ellis et al. (1990), coffee seeds are considered difficult to preserve due to their sensitivity to desiccation, which is classified as intermediate, i.e., they tolerate partial water loss during drying (up to $12 \%$ wet base) but do not tolerate storage at low temperatures $\left(<15^{\circ} \mathrm{C}\right)$.

Thus, techniques performed before sowing that allow better storage of these seeds are desirable. The attempt to develop techniques to accelerate germination and promote uniform seedling development is of great importance for coffee growers because allow sowing at better times for seedling development.

The priming technique is based on controlling seed hydration to a level that allows the initiation of all germination preparatory processes, but without the occurrence of cell elongation and the consequent radicle protrusion. Thus, at the end of priming, all seeds are expected to reach the same phase of the imbibition curve without reaching the radicle protrusion (Marcos-Filho, 2015).

Physiological priming, also called seed conditioning, is a presowing treatment to improve the speed and synchronicity of seed germination. The positive uses of using this technique has been seen in several species, with improvements in seed germination capacity and greater seed uniformity and vigor, such as Armondes et al. (2016) studying cabbage, Ruttanaruangboworn et al. (2017) investigating rice, Abid et al. (2018) with wheat and Arif et al. (2014) studying soybean seeds.

Several studies have been conducted with coffee using the physiological priming technique in an attempt to increase coffee seed germination, mainly investigating the temperature and physiological priming time in order to establish a suitable method for the species (Lima et al., 2004; Carvalho et al., 2012; Kikuti et al., 2013; Carvalho et al., 2014).

However, there are still few studies on coffee seeds that evaluate the effect of the physiological priming technique on seed quality in different phases of the storage and whether seed water content affects the worth of this technique. Thus, the objective of this study was to evaluate the effect of physiological priming on the physiological quality of seeds of two Coffea arabica cultivars stored with different water contents.

\section{MATERIAL AND METHODS}

The study was conducted at the Central Seed Laboratory of the Department of Agriculture of Universidade Federal de Lavras (UFLA). We used seeds from the 2017 harvest of Coffea arabica L. cultivars Catuaí Vermelho IAC 144 and Topázio MG 1190, provided by the Empresa de Pesquisa Agropecuária de Minas Gerais (EPAMIG).

Seeds with two water contents were used: freshly harvested wet seeds that were already marketed by the company, with 39\% and 41\% water content for Catuaí Vermelho IAC 144 and Topázio MG 1190, respectively, and seeds dried in the shade until reaching a water content $12 \%$.

After obtaining the seeds with the two water contents, they were placed in conventional raffia bags and packed in impermeable plastic bags. The bags were stored in a cold chamber at $10{ }^{\circ} \mathrm{C}$, and samples were collected every three months for nine months to determine the physiological quality of the seeds.

During the study period, the physiological priming technique was also performed in portions of the seeds in the two water-content groups. The technique was performed at the end of each storage period by removing 550 seeds and putting them in Erlenmeyer flasks with $400 \mathrm{~mL}$ of distilled water. The flasks were connected to a vacuum pump with plastic hoses for aeration of the internal environment and placed in a biochemical oxygen demand (BOD) chamber at $25{ }^{\circ} \mathrm{C}$ for seven days and the seeds was evaluated without drying. After this period, physiological quality evaluations were performed according to the tests and determinations described below. 
Water content determination: the water content was determined before performing the physiological priming technique using the oven drying method at $105^{\circ} \mathrm{C}$ for $24 \mathrm{~h}$ (Brasil, 2009), with two $20 \mathrm{~g}$ samples. The results, based on the wet weight, are expressed as percentages.

Germination test: this test was performed using four replicates of fifty seeds without the parchment, distributed on germination paper and moistened with an amount of water equivalent to 2.5 times the dry weight of the paper, with replacement of water according to necessary. The seeds were kept in a regulated germinator at $30^{\circ} \mathrm{C}$, and the percentage of normal seedlings was evaluated after 30 days, according to the criteria of the Rules for Seed Testing (Brasil, 2009).

Radicle protrusion: at fifteen days after the start of the germination test, the seedlings showing radicle emission were counted, and the results were expressed as percentages.

Normal seedlings at day 15: performed at fifteen days after the start of the germination test, when the normal seedlings, with a primary root and well-defined lateral roots, were counted according to the criteria of the Rules for Seed Testing (Brasil, 2009).

Strong normal seedlings: performed thirty days after the start of the germination test, the strong normal seedlings were evaluated according to the length of the hypocotyl axis. The plants considered strong normal were those with $\geq$ $3 \mathrm{~cm}$ in length.

Seedlings with expanded cotyledonary leaves: the evaluation was performed 45 days after the start of the germination test, when the seedlings with fully expanded cotyledonary leaves were counted. The results are expressed as percentages.

Seedling dry weight: performed 45 days after the beginning of the germination test, the normal seedlings were separated, stored in paper bags, and placed in a forced-air oven at $60^{\circ} \mathrm{C}$ for five days. After this period, the root and shoot dry weight and of the seedlings were determined, and the results are expressed in grams per seedling.

Experimental design and statistical analyses: the experimental design was completely randomized in a $4 \times 4$ factorial arrangement, with four seeds treatment (dry seeds primed, dry seeds unprimed, wet seeds primed and wet seeds unprimed) and four storage periods (0, 3, 6 and 9 months) for each cultivar. The data were subjected to analysis of variance and using the Scott-Knott test at the $5 \%$ significance level and analysis of regression at $5 \%$ probability was performed for storage periods, within SISVAR $^{\circledR}$ software (Ferreira, 2014).

\section{RESULTS AND DISCUSSION}

The seeds water content average values of two cultivars used in the study, determined after each storage period are contained in Table 1. It is possible to observe that the water content of the seeds did not change during storage, due to the type of used packaging, with values close to $39 \%$ and $41 \%$ for wet seeds (Catuaí Vermelho and Topázio, respectively) and $12 \%$ for dry seeds, with difference of less than $0.5 \%$ between the lowest and highest values. This uniformity ensured reliable evaluations of the seed's physiological potential.

Due to the results of the analysis of variance, there was a double interaction between seed treatment and storage period for all variables analyzed in the evaluation of the physiological quality of the seeds of the cultivar Catuai Vermelho. In the root protrusion test, it is possible to observe that, for the cultivar in discussion, the physiological priming technique affected the quality of dry seeds in most of the storage months evaluated, with the exception of six months. For wet seeds of the cultivar Catuaí Vermelho, there was no difference between those that were submitted to priming and unprimed seeds (Figure 1).

The results of the germination test confirm that the use of the physiological priming technique in seeds with low water content (12\%) affects seedling development, where after three months of storage, they had the lowest germination values when compared to other treatments (Figure 2).

The percentage of germination of primed wet seeds, and wet ones without priming, were very close, with no difference between them during the nine months of storage. Similarly, Carvalho et al. (2012), when using the physiological 
priming technique in solid matrix, did not find differences in the germination percentage of Coffea arabica seeds after eight days of priming. Dry seeds unprimed also showed a close trend, with a fall after six months (Figure 2).

Table 1. Seeds water content average values ( $\mathrm{wb}^{*}$ ) of different Coffea arabica cultivars obtained after each storage period.

\begin{tabular}{cccc}
\hline \multirow{2}{*}{ Cultivar } & Storage (months) & Wet & Moisture (\%) \\
\cline { 3 - 4 } & 0 & 39.17 & 12.89 \\
Catuaí Vermelho IAC 144 & 3 & 39.16 & 12.58 \\
& 6 & 39.44 & 12.99 \\
& 9 & 39.06 & 12.91 \\
\hline \multirow{2}{*}{ Topázio MG 1190 } & 0 & 41.01 & 12.30 \\
& 3 & 41.08 & 12.15 \\
& 6 & 41.48 & 12.34 \\
\hline
\end{tabular}

$w^{*}$ : wet base

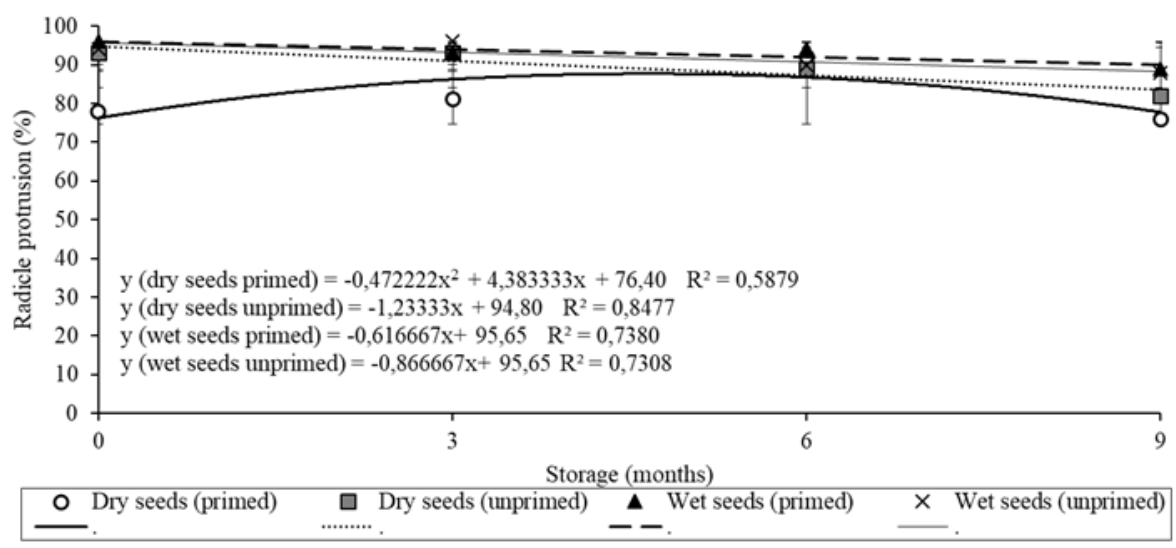

Figure 1. Percentage of radicle protrusion from seeds of Coffea arabica cv. Catuaí Vermelho with different moisture levels and subjected to physiological priming throughout storage.

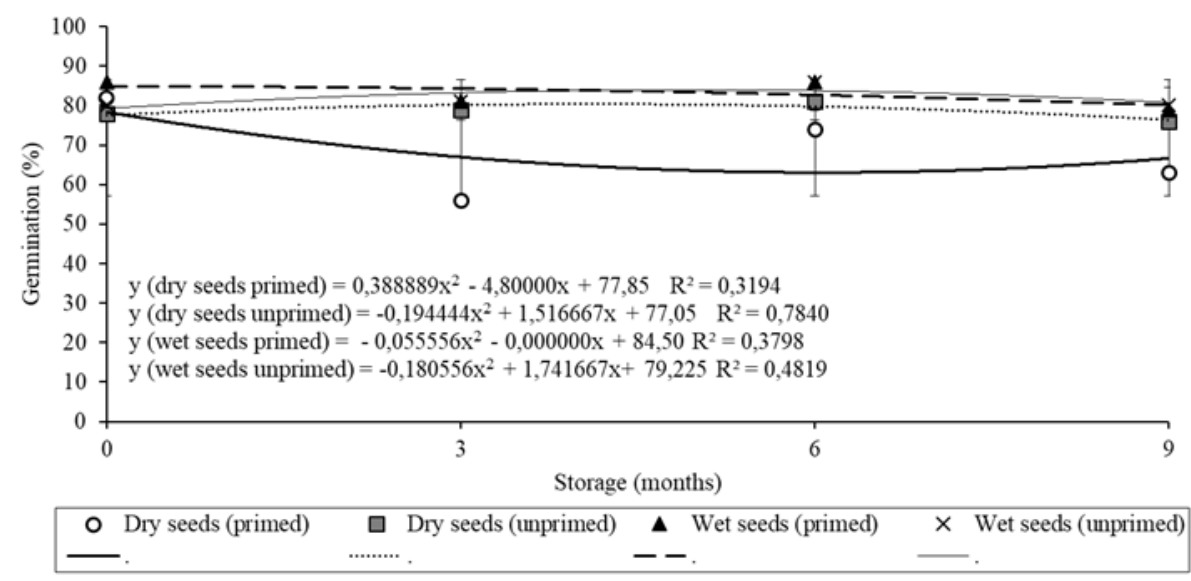

Figure 2. Percentage of germination from seeds of Coffea arabica cv. Catuaí Vermelho with different moisture levels and subjected to physiological priming throughout storage. 
Marcos-Filho (2015) reports that rapid hydration of seeds can cause damage, with death of surface cells and greater loss of exudates. The fact that the dried seeds had low water content when coming into direct contact with water may have caused such damage to the seeds. This explains what was found in our study, where the dry seeds presented lower percentages of germination test and radicular protrusion than the wet seeds, both subjected to the physiological priming technique.

In the evaluation of normal seedlings at fifteen days (Figure 3), higher percentages are observed for those primed seeds, regardless of the storage period evaluated. This shows that the technique was efficient in accelerating seedling development, though this process was more favorable to the development of wet seeds than dry seeds.

Anese et al. (2011), working with tomato seeds, found that the hydropriming technique, that is, imbibition of seeds only in water, was favorable to seedling development. Lima et al. (2004) also found that physiological priming in water promotes greater germination and vigor in coffee seeds, in line with what was seen in this study.

The results show that the unprimed dry and wet seeds showed normal seedling values at fifteen days, close to zero, for all evaluated storage periods. The primed seeds obtained a significant number of normal seedlings at fifteen days, and for wet primed seeds this value was higher, but after six months of storage there was a drop, however, even higher than the seeds that have not been primed.

According to Marcos-Filho (2015), physiological priming is not able to promote increased seed germination because seeds are not regenerated. This effect was also seen here, though it should be noted that physiological priming benefited the seeds. The first germination count is a test associated with germination but that expresses seed vigor. Pallaoro et al. (2016), when studying the effect of physiological priming on corn seeds, also found higher percentages of normal seedlings in the first count, and different from what was observed in this study, the authors also emphasized improvements in the final seed germination percentage.

In the same way as observed in the evaluation of normal seedlings at fifteen days, the results of strong normal seedlings were higher in primed seeds, regardless of the water content, except for nine months of storage, where dry seeds unpriming did not differ from primed seeds (Figure 4). For the percentage of expanded cotyledon leaves, the same result was observed in wet seeds in most storage periods, showing that the technique was efficient maintaining the vigor of wet seeds after the storage period (Figure 5).

Armondes et al. (2016), when evaluating cabbage seeds subjected to the physiological priming technique, observed the benefits of osmopriming in artificially aged seeds. Arif et al. (2014) also found benefits of using the physiological priming technique in soybean seeds, obtaining positive seed vigor results.

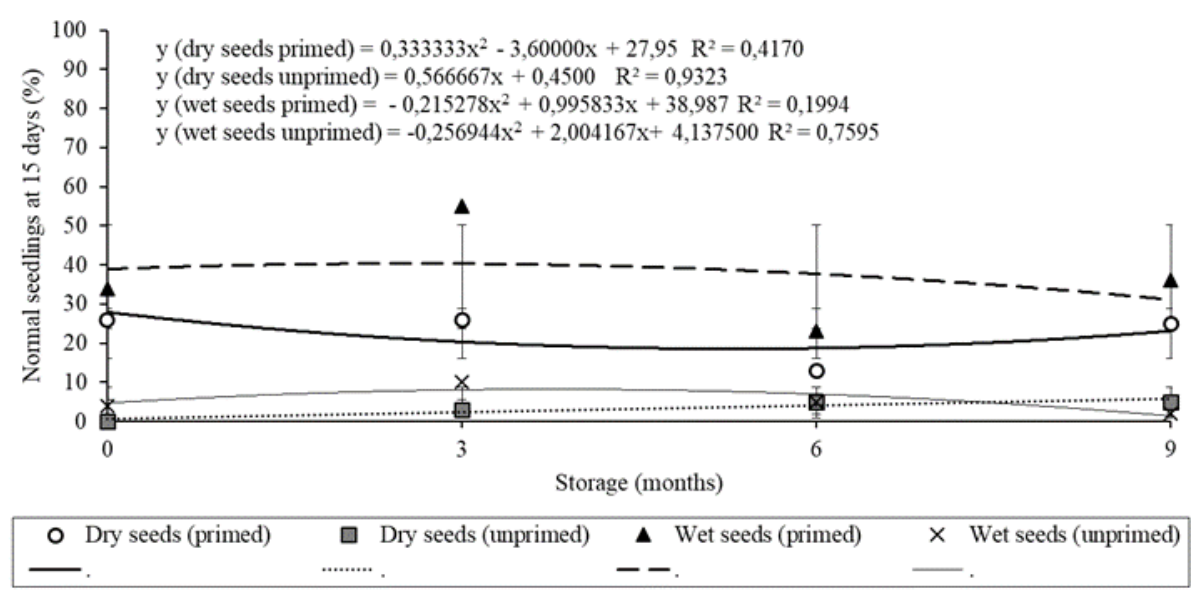

Figure 3. Percentage of normal seedlings at fifteen days from seeds of Coffea arabica cv. Catuaí Vermelho with different moisture levels and subjected to physiological priming throughout storage. 


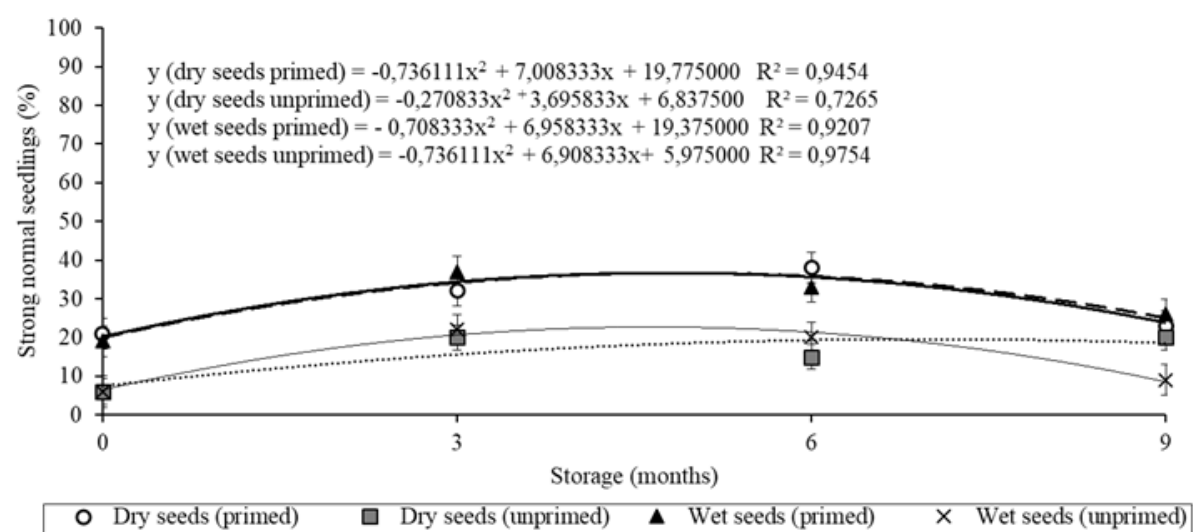

Figure 4. Percentage of strong normal seedlings from seeds of Coffea arabica cv. Catuaí Vermelho with different moisture levels and subjected to physiological priming throughout storage.

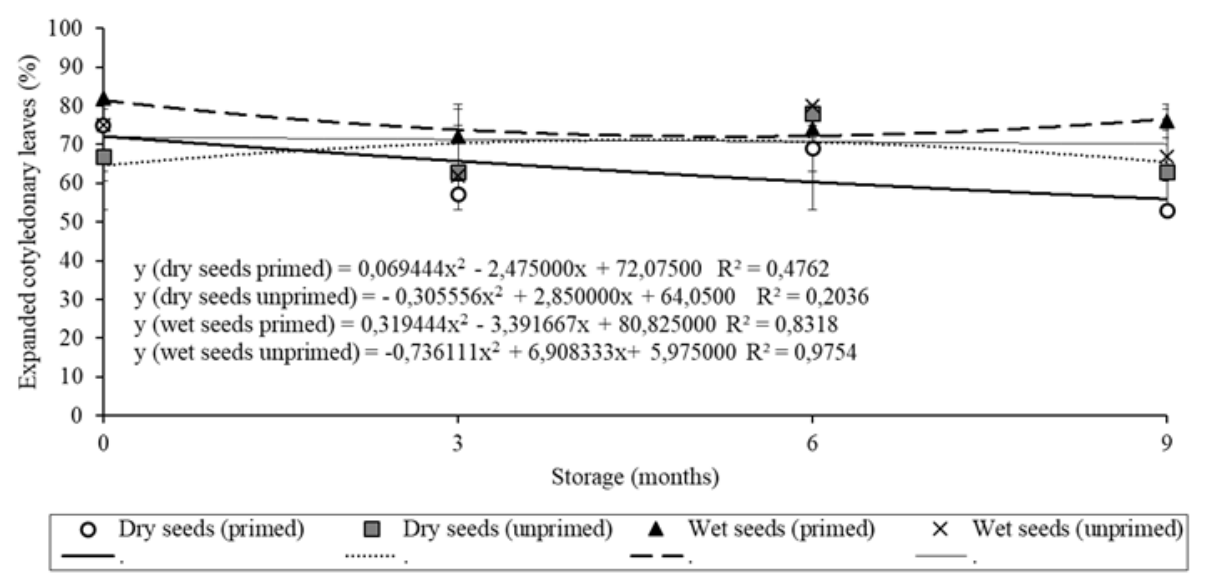

Figure 5. Percentage of expanded cotyledonary leaves from seeds of Coffea arabica cv. Catuaí Vermelho with different moisture levels and subjected to physiological priming throughout storage.

As for dry seeds, this fact was not observed, since after three months of storage, the percentage of seedlings with expanded cotyledon leaves was higher when the seeds were not subjected to physiological priming (Figure 5). This fact confirms what was previously observed in Figure 1 for germination and normal seedlings at fifteen days, showing that the use of physiological priming in dry seeds is detrimental to the quality of the seeds of the cultivar Catuaí Vermelho stored.

According to Marcos-Filho (2015), dry seeds exhibit changes in the configuration of membrane phospholipids after dehydration. In addition, this author reported a direct dependence on the speed and intensity of exudate release and the organization of the cell membrane system. Thus, at the beginning of the imbibition process, the seeds absorb water more quickly, which can lead to the leakage of cell solutes from the disordered membranes. This damage can cause a loss of seed quality and a longer time for membrane reorganization.

In the literature, several studies have shown that the use of osmotic agents, which regulate water flow, are effective in reducing the damage caused by the rapid imbibition of dry seeds. Sediyama et al. (2012) found a reduction in damage and lesions in soybean seeds after the use of osmopriming. Pallaoro et al. (2016) also saw this effect when using an osmotic agent in the priming of corn seeds.

In the present study, no priming agent was used, and the physiological priming of the seeds was done only in water. This explains the fact that the results of the primed dry seeds were not satisfactory to maintain their physiological 
quality, although this is the most suitable technique for coffee seeds according to the literature.

The Figure 6 shows the dry mass data of the coffee seedlings, and based on the results, it is possible to observe that for all treatments used, the results were similar and with little variation in the weight of the dry mass of the roots. At six months of storage, it is noted that primed dry seeds have the lowest root dry mass values (Figure 6A).

The primed wet seeds exhibited greater uniformity in shoot dry weight throughout the storage period, and this result corroborates that seen in the evaluation of seedlings with expanded cotyledonary leaves in Figure 5 . This result is important because coffee seeds show nonuniform development and rapid loss of vigor after storage. Eira et al. (2006) stated that mature coffee seeds displayed slow and asynchronous germination and that this factor made it difficult to obtain ideal seedlings for the establishment of coffee plantings and subsequent production.

Other studies indicate a positive effect of physiological priming on seed vigor. Kaur et al. (2002), working with chickpea seeds, found that hydropriming led to an increase in the shoot length of seedlings compared to seedlings obtained from unprimed seeds. Aloui et al. (2014) also found positive results from the physiological priming technique in pepper seeds, especially in the initial stages of seedling development.

In the results obtained in the analysis of variance for the cultivar Topázio MG1190, an isolated effect of the seed treatment factor was observed for the root protrusion variable. For the other variables, there was a double interaction between the factors of seed treatment and storage periods.

In Table 2, represented by the results of root protrusion of coffee seeds, it is possible to observe that dry and primed seeds had the lowest percentages when compared to the other treatments. This result corroborates with
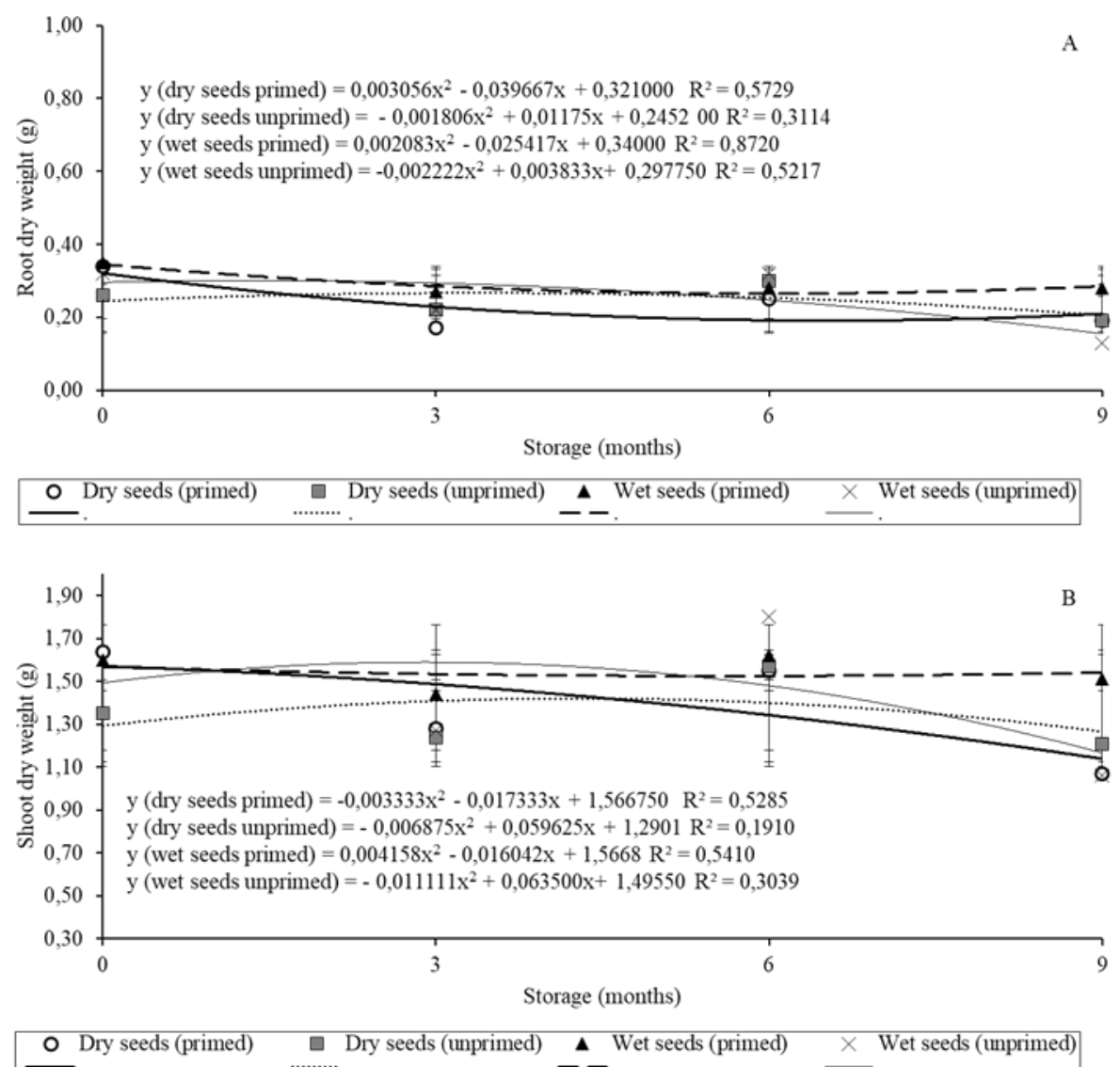

Figure 6. Root dry weight (A) and shoot dry weight (B) of seedlings, in grams, at 45 days after sowing of seeds of Coffea arabica cv. Catuaí Vermelho with different moisture levels and subjected to physiological priming throughout storage. 
what was observed in this study for the cultivar Catuaí Vermelho, in which the dry seeds do not tolerate the priming technique due to their low water content.

Xia et al. (2017) found similar results when working with physiological priming in oat seeds. The authors reported a lower germination percentage for very dry (4\%) and aged seeds subjected to hydropriming. The authors also report that when using polyethylene glycol (PEG), dry and aged seeds had higher germination percentages than other seeds, subjected or not to hydropriming.

In the seed imbibition process, there is a reorganization of the cellular constituents, and as hydration of the tissues occurs, the seeds acquire sensitivity to rapid imbibition, so they may release a greater amount of solutes and restart metabolism in a defective manner (Marcos-Filho, 2015). The same study reports that, under conditions of a large difference between the water potential of the seed and that of the substrate, damage can have a stronger effect on germination. This finding may explain the results of our study.

In the results of the percentage of normal seedlings fifteen days after germination, it is observed that, just as it occurred in the cultivar Catuaí Vermelho, primed seeds have superior performance, whether dry or wet seed (Figure 7). However, it is important to note that wet primed seeds have even higher values when compared to dry seeds that have also undergone the same hydropriming process. This pattern was not seen when the wet and dry seeds were not subjected to priming, as their percentage of normal seedlings at fifteen days was equals and close to zero along all storage period. It is also observed that for primed seeds, despite the high values found, there is a tendency for the vigor to decrease as the storage period progresses.

In the germination test, it was only possible to observe differences between treatments in the first months of storage (Figure 8). The primed wet seeds had the highest germination averages when compared to the others, evaluated

Table 2. Percentage of radicle protrusion (RP) of seeds of Coffea arabica cv. Topázio MG 1190 at different moisture levels and subjected to physiological priming.

\begin{tabular}{cc}
\hline Seeds treatments & Radicle protrusion (\%) \\
\hline Dry seeds primed (DSP) & $88 \mathrm{~b}$ \\
Dry seeds unprimed (DSU) & $93 \mathrm{a}$ \\
Wet seeds primed (WSP) & $93 \mathrm{a}$ \\
Wet seeds unprimed (WSU) & $92 \mathrm{a}$ \\
\hline C.V. & 4.06 \\
\hline
\end{tabular}

Means followed by the same letter do not differ from each other by the Scott-Knott test at $5 \%$ probability.

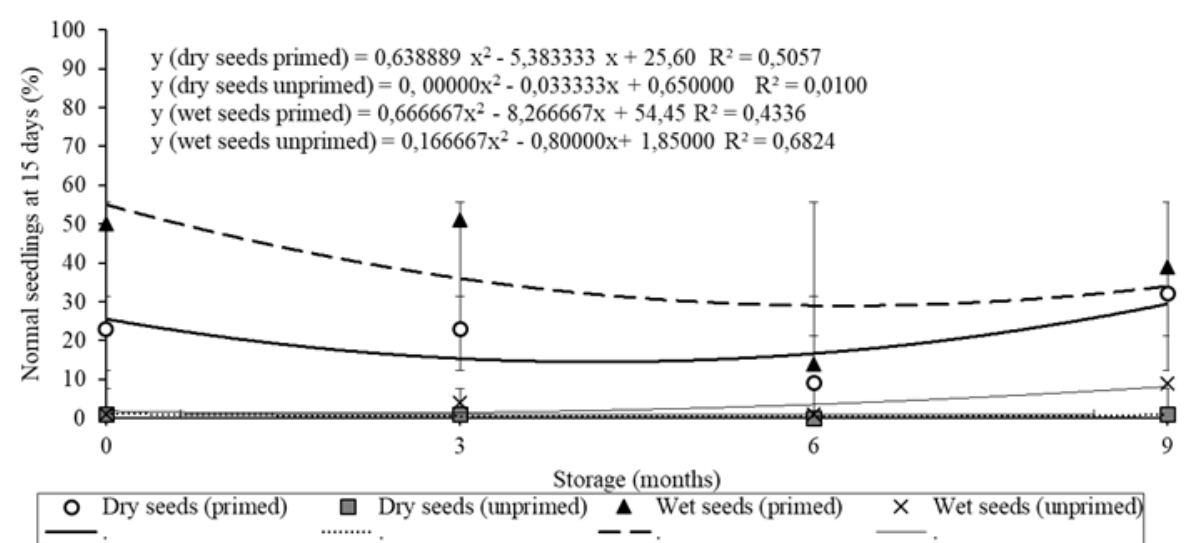

Figure 7. Percentage of normal seedlings at fifteen days after sowing of seeds Coffea arabica cv. Topázio MG 1190 with different moisture levels and subjected to physiological priming throughout storage. 
freshly harvested. After three months of storage, only primed dry seeds had lower germination values, however, this fact cannot be observed in subsequent storage periods. This result shows that for seeds of high physiological quality, the use of the physiological priming technique after storage is not able to increase the germination percentage.

Gomes et al. (2012) investigated osmotic priming in eggplant seeds and did not find improvements in the percentage germination of the seeds after priming but did find positive effects of the technique on seed vigor.

Galhaut et al. (2014) also did not find an effect of physiological priming on the germination percentage of Trifolium repens L. seeds. However, the same authors emphasize that in heavy metal-contaminated soil, primed seeds exhibited superior growth compared to those that did not undergo priming. Other authors, such as Chen et al. (2013), Jisha et al. (2013) and Farahani and Maroufi (2011), also reported benefits to seed development under stress conditions using the physiological priming technique.

The results of the percentage of strong normal seedlings underscore the importance of seed vigor, because although the germination test does not show significant differences, it shows that after storage primed seeds have higher values and more vigorous seedlings when compared to the seeds that have not gone through the hydropriming process. Despite this, it is observed in the regression graph (Figure 9), that after three months of storage the percentage of strong normal seedlings increases, however, after this period there has been a gradual decrease in their vigor, a fact

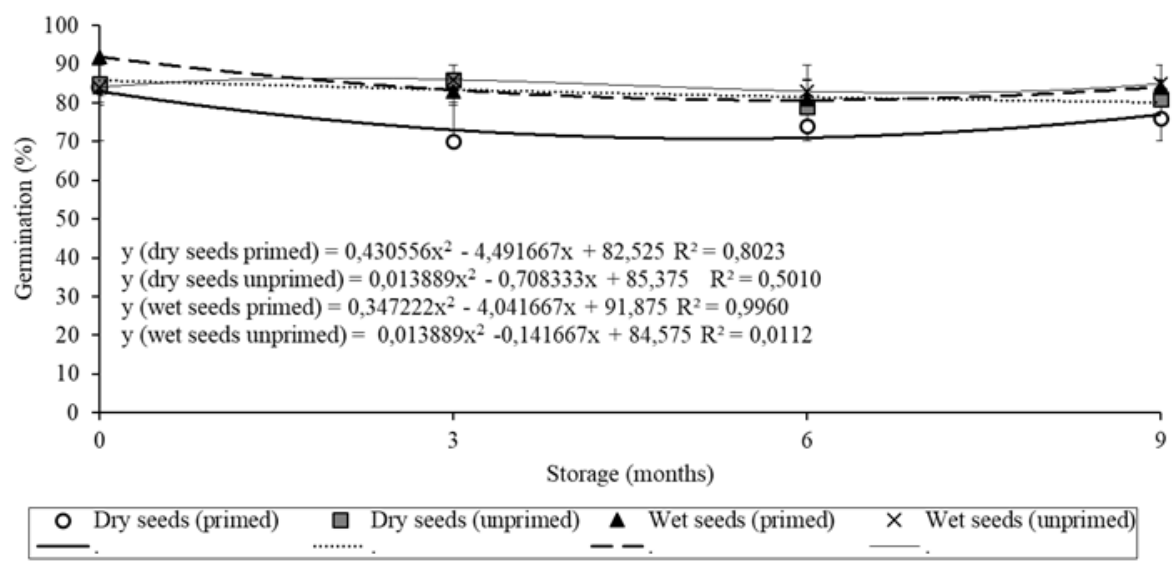

Figure 8. Percentage of germination of seeds Coffea arabica cv. Topázio MG 1190 with different moisture levels and subjected to physiological priming throughout storage.

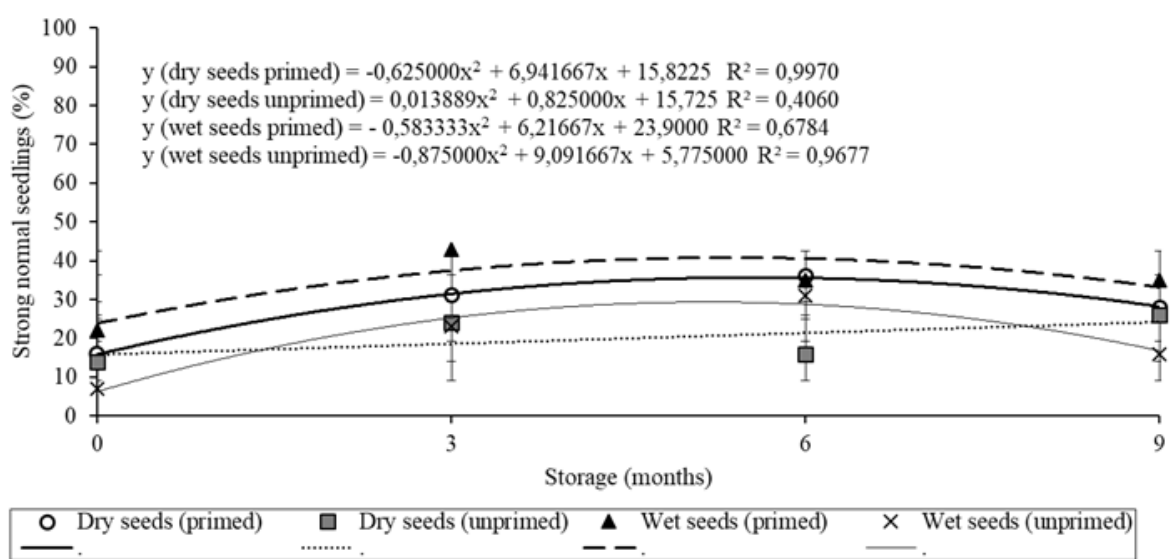

Figure 9. Percentage of strong normal seedlings of seeds Coffea arabica cv. Topázio MG 1190 with different moisture levels and subjected to physiological priming throughout storage. 
that can be explained due to seed deterioration. It is possible to note that, as observed for other variables, primed dry seeds presented the lowest values at nine months of storage.

The analysis of seed vigor is important to differentiate lots that present the same percentage of germination, however they differ with high or low performance during storage and also when sowing in the field (Marcos-Filho, 2015). According to Trujillo et al. (2019) in coffee seeds, this evaluation is important, due to slow germination and loss of physiological quality during storage, factors considered critical for the species.

In the evaluation of the percentage of seedlings with expanded cotyledon leaves, it is observed that in the freshly harvested wet seeds, the use of the physiological priming technique was relevant to increase the number of seedlings with development of cotyledon leaves, when compared to the other treatments (Figure 10). After storage, only primed dry seeds differ from others with lower percentages, confirming that the use of physiological conditioning was detrimental to seedling development. In addition, it is observed in the wet seeds showed a similar and uniform of the evaluation of cotyledon leaves behavior throughout the storage period. In dry unprimed seeds there is a drop in vigor after six months of storage.

For the variable dry mass of roots, it is possible to observe that the freshly harvested and primed seeds showed higher values than other treatments (Figure 11A). However, during storage these differences are not possible, and therefore we cannot conclude anything about the influence of water content and the physiological priming technique for the variable in discussion. It is possible to notice a reduction in the vigor of the wet and dry seeds primed to the three months of storage.

The results obtained for the dry mass of the aerial part of the coffee seedlings corroborate with what was observed in most of the variables analyzed in the study, in which the primed wet seeds present the highest values when freshly harvested (Figure 11B). At three and six months of storage, only dry and primed seeds showed lower values of seedling dry mass. This confirms the fact that the dried seeds suffered damage during the imbibition process in the physiological priming.

In general, the results indicate that for high-quality seed lots, the use of physiological priming is not effective in improving germination percentage, and for wet seeds primed and unprimed there are no improvements in most vigor tests for the cultivar Topázio MG 1190, which maintained the physiological quality of seeds even after nine months of storage. As for seed lots with medium vigor of the Catuaí Vermelho cultivar, physiological priming was effective in improving the vigor of the wet seeds, but there was no improvement in the final germination percentage.

Caseiro et al. (2004) observed this same behavior when comparing six lots of onion seeds. The authors concluded that physiological priming was not effective in seed lots with high quality, but in those considered of medium vigor, the technique had a positive effect. The authors also concluded that the water content of seeds before and after priming is

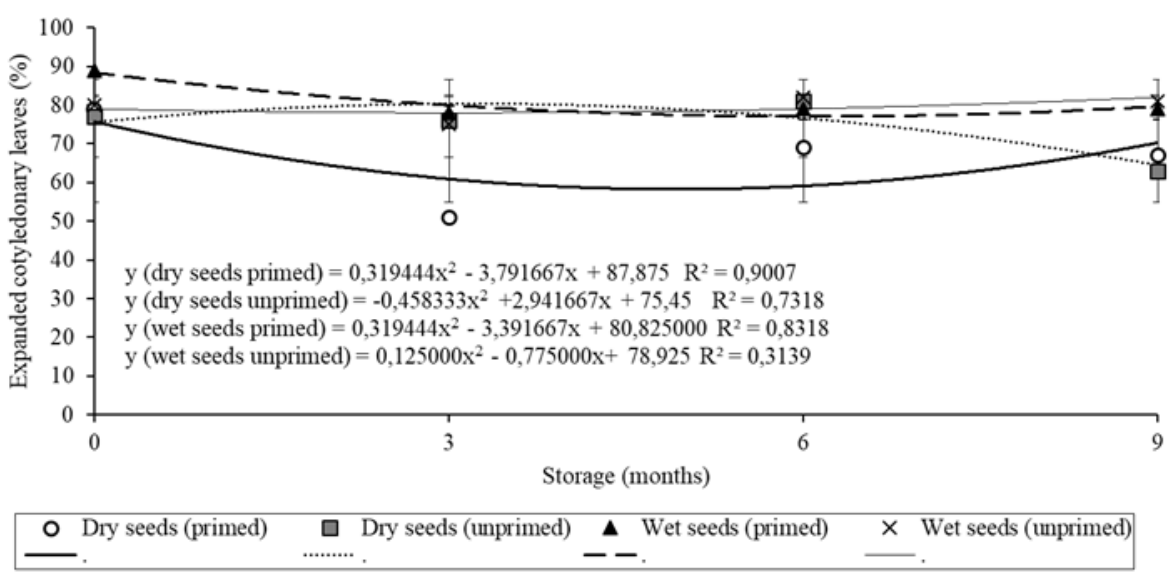

Figure 10. Percentage of expanded cotyledonary leaves of seedlings at 45 days after sowing of seeds of Coffea arabica cv. Topázio MG 1190 with different moisture levels and subjected to physiological priming throughout storage. 

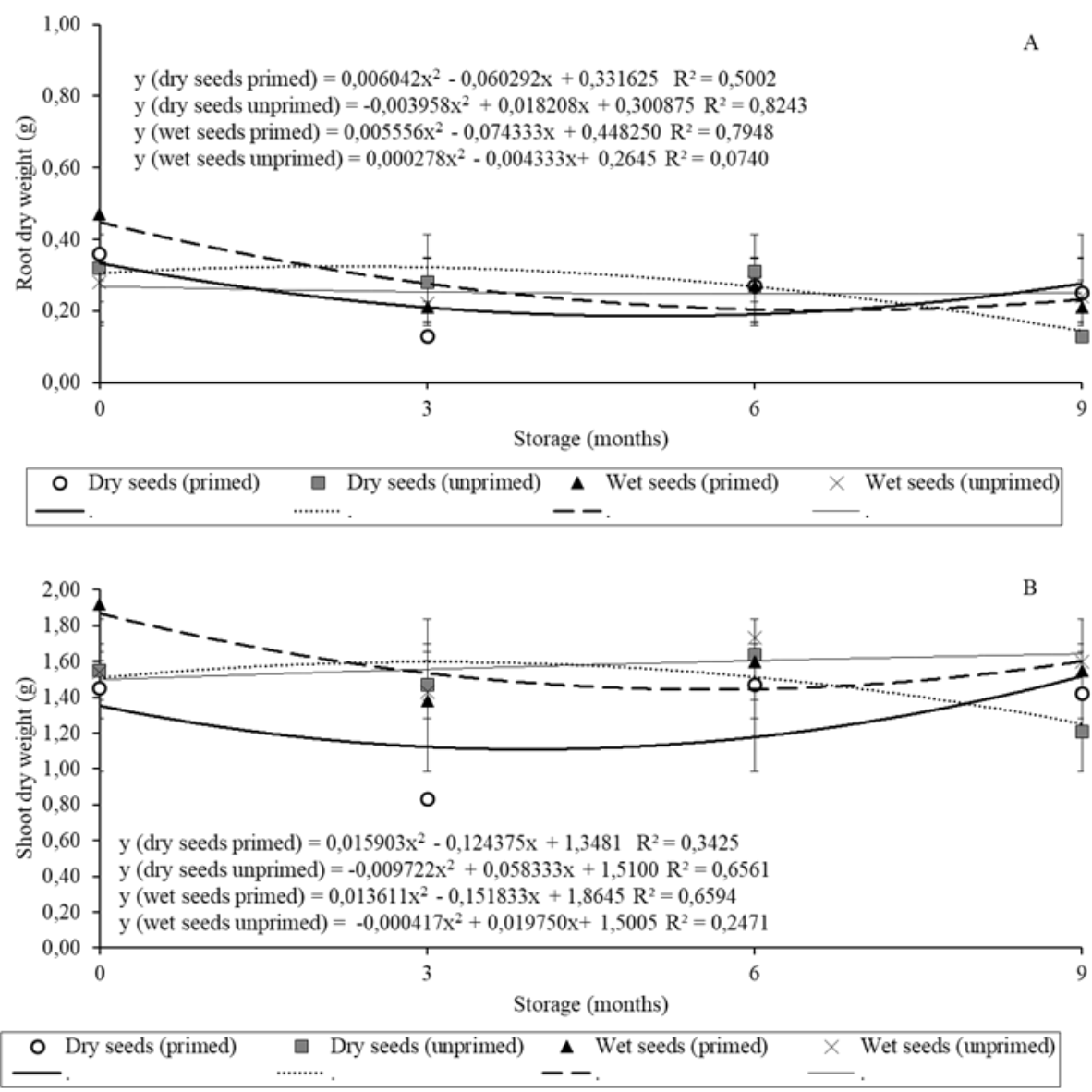

Figure 11. Root dry weight (A) and shoot dry weight (B) of seedlings, in grams, at 45 days after sowing of seeds of Coffea arabica cv. Topázio MG 1190 with different moisture levels and subjected to physiological priming throughout storage.

an important factor when choosing the best method to use. Silva et al. (2016) also reported that physiological priming in medium-vigor seeds has a positive effect on soybean production and productivity components.

Although there was no difference in the final seed germination percentage for Topázio MG1190, it was found that for seed vigor, there was a positive effect of using the physiological priming technique. These results show that under water, salinity, and temperature stress conditions, during the early stage of seedling development, those grown from primed seeds may present greater resistance and thus show superior results. This finding has also been reported by several authors in different species, such as clover (Galhaut et al., 2014), chickpea (Kaur et al., 2002), wheat (Abid et al., 2018), and carrot (Nascimento et al., 2013).

Further studies on the effects of physiological priming on seed vigor during seedling formation are needed. The reported benefits justify the use of vigorous seeds or seeds subjected to priming, thus allowing faster and uniform seedling establishment, a factor that is important for obtaining higher yields.

\section{CONCLUSIONS}

Seeds that did not undergo drying subjected to the physiological priming technique maintained physiological quality after nine months of storage.

Physiological priming was detrimental to dry seeds stored for nine months. 


\section{REFERENCES}

ABID, M.; HAKEEM, A.; SHAO, Y.; LIU, Y.; ZAHOOR, R.; FAN, Y.; SUYU, J.; ATA-UL-KARIM, S.T.; TIAN, Z.; JIANG, D.; SNIDER, J.L.; DAI, T. Seed osmopriming invokes stress memory against post-germinative drought stress in wheat (Triticum aestivum L.). Environmental and Experimental Botany, v.145, p.12-20, 2018. https://doi.org/10.1016/j.envexpbot.2017.10.002

ALOUI, H.; SOUGUIR, M.; LATIQUE, S.; HANNACHI, C. Germination and growth in control and primed seeds of pepper as affected by salt stress. Cercetari Agronomice in Moldova, v.47, n.3, p.83-95, 2014. https://doi.org/10.2478/cerce-2014-0029

ANESE, S.; SILVA, E.A.A.; DAVIDE, A.C.; ROCHA FARIA, J.M.; SOARES, G.C.M.; MATOS, A.C.B.; TOOROP, P.E. Seed priming improves endosperm weakening, germination, and subsequent seedling development of Solanum lycocarpum St. Hil. Seed Science and Technology, v.39, n.1, p.125-139, 2011. https://doi.org/10.15258/sst.2011.39.1.11

ARIF, M.; JAN, M.T.; MIAN, I.A.; KHAN, S.A.; HOLLINGTON, P.; HARRIS, D. Evaluating the impact of osmopriming varying with polyethylene glycol concentrations and durations on soybean. International Journal of Agriculture and Biology, v.16, n.2, p.359364, 2014. https://www.researchgate.net/publication/260284685

ARMONDES, K.A.P.; DIAS, D.C.F.S.; MARTíNEZ, P.A.H.; SILVA, L.J.; HILST, P.C. Condicionamento osmótico e desempenho de sementes de repolho com diferentes níveis de vigor. Horticultura Brasileira, v.34, n.3, p.428-434, 2016. https://doi.org/10.1590/S010205362016003020

BRASIL. Ministério da Agricultura, Pecuária e Abastecimento. Regras para análise de sementes. Ministério da Agricultura, Pecuária e Abastecimento. Secretaria de Defesa Agropecuária. Brasília: MAPA/ACS, 2009. 399p. http:// https://www.gov.br/agricultura/ptbr/assuntos/insumos-agropecuarios/arquivos-publicacoes-insumos/2946_regras_analise_sementes.pdf

CARVALHO, C.A.M.; ALMEIDA, T.T.; GUIMARÃES, R.M. Plântulas de café originadas de sementes armazenadas e submetidas ao condicionamento fisiológico em matriz sólida. Nativa, v.2, n.3, p.166-169, 2014. http://dx.doi.org/10.14583/2318-7670.v02n03a07

CARVALHO, C.A.M.; GUIMARÃES, R.M.; SILVA, T.T.A. Condicionamento fisiológico em matriz sólida de sementes de café (Coffea arabica L.) com e sem pergaminho. Revista Brasileira de Sementes, v.34, n.1, p.94-98, 2012. http://dx.doi.org/10.1590/S010131222012000100012

CASEIRO, R.; BENNETT, M.A.; MARCOS-FILHO, J. Comparison of three priming techniques for onion seed lots differing in initial seed quality. Seed Science and Technology, v.32, n.2, p.365-375, 2004. https://doi.org/10.15258/sst.2004.32.2.09

CHEN, K.; FESSEHAIE, A.; ARORA, R. Aquaporin expression during seed osmopriming and post-priming germination in spinach. Biologia Plantarum, v.57, n.1, p.193-198, 2013. https://doi.org/10.1007/s10535-012-0266-0

CONAB. Companhia Nacional de Abastecimento. Análise do mercado: análise mensal café, levantamento junho/julho 2020. https:// www.conab.gov.br/info-agro/analises-do-mercado-agropecuario-e-extrativista/analises-do-mercado/historico-mensal-de-cafe

EIRA, M.T.S.; SILVA, E.A.A.; CASTRO, R.D.; DUSSERT, S.; WALTERS, C.; BEWLEY, D.; HILHORST, H.W.M. Coffee seed physiology. Brazilian Journal of Plant Physiology, v.18, n.1, p.149-163, 2006. https://doi.org/10.1590/S1677-04202006000100011

ELLIS, R.H.; HONG, T.D.; ROBERTS, E.H. An intermediate category of seed storage behavior? I. Coffee. Journal of Experimental Botany, v.41, n.230, p.1167-1174, 1990. https://doi.org/10.1093/jxb/41.9.1167

FARAHANI, H.A.; MAROUFI, K. Effect of hydropriming on seedling vigour in basil (Ocimum basilicum L.) under salinity conditions. Advances in Environmental Biology, v.5, p.828-833, 2011. http://scinet.dost.gov.ph/union/Downloads/828-833_225123.pdf

FERREIRA, D.F. SISVAR: a guide for its bootstrap procedures in multiplecomparisons. Ciência e Agrotecnologia, v.38, n.4, p.278-286, 2014. https://doi.org/10.1590/S1413-70542014000200001

GALHAUT, L.; LESPINAY, A.; WALKER, D.J.; BERNAL, M.P.; CORREAL, E.; LUTTS, S. Seed priming of Trifolium repens L. improved germination and early seedling growth on heavy metal-contaminated soil. Water, Air, and Soil Pollution, v.225, n.4, p.1905, 2014. https://doi.org/10.1007/s11270-014-1905-1

GOMES, D.P.; SILA, A.F.; DIAS, D.C.F.S.; ALVARENGA, E.M.; SILVA, L.J.; PANOZZO, L.E. Priming and drying on the physiological quality of eggplant seeds. Horticultura Brasileira, v.30, n.3, p.484-488, 2012. https://doi.org/10.1590/S0102-05362012000300021 
JISHA, K.C.; VIJAYAKUMARI, K.; PUTHUR, J.T. Seed priming for abiotic stress tolerance: an overview. Acta Physiologiae Plantarum, v.35, n.5, p.1381-1396, 2013. https://doi.org/10.1007/s11738-012-1186-5

KAUR, S.; GUPTA, A.K.; KAUR, N. Effect of osmo- and hydropriming of chickpea on seedling growth and carbohydrate metabolism under water deficit stress. Plant Growth Regulation, v.37, p.17-22, 2002. https://doi.org/10.1023/A:1020310008830

KIKUTI, A.L.P.; PEREIRA, C.E.; KIKUTI, H.; GUIMARÃES, R.M. Coffee seeds water imbibition at different periods and temperatures. Revista Acadêmica Ciência Animal, v.11, n.S2, p.51 - 57, 2013. https://doi.org/10.7213/academica.10.S02.A006

LIMA, S.M.P.; GUIMARÃES, R.M.; OLIVEIRA, J.A.; VIEIRA, M.G.G.C. Efeitos de tempos e temperaturas de condicionamento sobre a qualidade fisiológica de sementes de cafeeiro (Coffea arabica L.) sob condições ideais e de estresse térmico. Ciência e Agrotecnologia, v.28, n.3, p.506-514, 2004. https://doi.org/10.1590/S1413-70542004000300004

MARCOS-FILHO, J. Fisiologia de sementes de plantas cultivadas. 2. ed. Londrina: ABRATES, 2015. 660p.

NASCIMENTO, W.M.; HUBER, D.J.; CANTLIFFE, D.J. Carrot seed germination and respiration at high temperature in response to seed maturity and priming. Seed Science and Technology, v.41, p.164-169, 2013. https://doi.org/10.15258/sst.2013.41.1.19

PALLAORO, D.S.; CAMILI, E.C.; GUIMARÃES, S.C.; ALBUQUERQUE, M.C.F. Methods for priming maize seeds. Journal of Seed Science, v.38, n.2, p.148-154, 2016. https://doi.org/10.1590/2317-1545v38n2161132

RUTTANARUANGBOWORN, A.; CHANPRASERT, W.; TOBUNLUEPOP, P.; ONWIMOL, D. Effect of seed priming with different concentrations of potassium nitrate on the pattern of seed imbibition and germination of rice (Oryza sativa L.). Journal of Integrative Agriculture, v.16, n.3, p.605-613, 2017. https://doi.org/10.1016/S2095-3119(16)61441-7

SEDIYAMA, C.A.Z.; REIS, M.S.; SEDIYAMA, C.S.; DIAS, M.A.; SEDIYAMA, T.; DIAS, D.C.F.S. Physiological quality of soybean seed cultivars by osmoconditioning. Comunicata Scientiae, v.3, n.2, p.90-97, 2012. https://www.comunicatascientiae.com.br/ comunicata/article/view/88

SILVA, T.A.; SILVA, P.B.; SILVA, E.A.A.; NAKAGAWA, J.; CAVARIANI, C. Condicionamento fisiológico de sementes de soja, componentes de produção e produtividade. Ciência Rural, v.46, n.2, p.227-232, 2016. https://doi.org/10.1590/0103-8478cr20141736

TRUJILLO, H.A.; GOMES-JUNIOR, F.G.; CICERO, S.M. Digital images of seedling for evaluating coffee seed vigor. Journal of Seed Science, v.41, n.1, p.60-68, 2019. https://doi.org/10.1590/2317-1545v41n1204651

XIA, F.S.; WANG, M.Y.; CHEN, L.L.; CHENG, H.; SUN, Y.; LI, M.L.; DONG, K.H.; ZHAO, X.; MAO, P.S. Responses of mitochondrial ultrastructure and physiological variations to PEG-priming on ultra-dried oat (Avena sativa L.) seeds after ageing. Seed Science and Technology, v.45, p.622-637, 2017. https://doi.org/10.15258/sst.2017.45.3.02 use, distribution, and reproduction in any medium, provided the original work is properly cited. 